\title{
Modern Features for Capital Portfolio Monitoring
}

Submitted 05/01/19, 1st revision 17/02/19, 2nd rervision 26/04/19, accepted 16/05/19

\section{Posnaya, E.A. ${ }^{1}$, Semenyuta, O.G. ${ }^{2}$, Dobrolezha, E.V. ${ }^{3}$, Smolander, M. $^{4}$}

\begin{abstract}
:
Purpose: Banking activity calls for new requirements, approaches, conditions, and mechanisms of the bank's liabilities management. Capital portfolio monitoring is an integral part of bank management. This study focuses on and proposes a quality criterion for the bank's capital portfolio, which has never been used by banking institutions so far.

Design/Methodology/Approach: The proposed criterion represents a link between the banking sector and the common vector of Russia's current economic development and functioning. It takes into consideration the condition of macroeconomics, tendencies of the modern financial market and basic guidelines of the banking sector.

Findings: Authors proved that the banking institution's capital portfolio analysis is impossible without monitoring activities. The process of permanent monitoring of the formation used, and the performance of banking capital need to be constantly improved, according to current trends in economic, social, political, and financial spheres. The study proposes new schemes, considering the current condition of the banking sector, macroeconomics and the regional social-economic environment.
\end{abstract}

Practical Implications: The results may be implemented into activity of the Russian banking sector to improve the effectiveness of its business activity.

Originality/Value: The study proposes a unique quality criterion for the bank's capital portfolio monitoring as an integral part of bank management.

Keywords: Monitoring capital portfolio, banking institution, quality.

JEL codes: F60, F63, O35, O44.

Paper Type: Research article in Special Issue dedicated to Russian Economy.

Section 2: Banking \& Finance.

${ }^{1}$ Candidate of Science (Economics), Associate Professor of the Department of "Finance", Sevastopol State University, Sevastopol, sntulena@mail.ru

${ }^{2}$ Doctor of Science (Economics), Professor of Rostov State University of Economics, Rostovon-Don,ogsmail1@mail.ru

${ }^{3}$ Doctor of Science (Economics), Professor of Rostov State University of Economics, Rostovon-Don,dobroleja.elena@yandex.ru

${ }^{4}$ Ph.D., Senior Lecturer in Business Administration, School of Social Sciences, Södetörn

University, Huddinge, maria.smolander@sh.se 


\section{Introduction}

The approach used in this study outlines modern characteristic features of the banking institution's capital portfolio monitoring and justifies viability of the systematic approach to the content of this process. It gives a broad view of specific circumstances in which a banking institution operates while forming its capital portfolio. A new quality criterion for the capital portfolio is proposed, which reflects participation of the banking system in meeting the key targets of the Russian Federation's social-economic development. The relevance of the given approach is supported by the results of the most recent scientific studies in the field of successful functioning of the banking system, changeability of the main approaches to the mission of commercial banks as financial intermediaries in times of crisis and postcrisis, which is aimed at the promotion of economic development of the country and its individual regions. The aforesaid justifies an objective necessity to analyze the quality of capital portfolio considering its correspondence to the criteria of profitability, risk, purposefulness and liquidity.

The aim of this study is to reveal certain characteristics of a banking institution's capital portfolio monitoring under modern conditions. The study proposes a methodological approach towards development of integral assessment of the capital portfolio quality, which provides a complex approach to assessment of quality of capital portfolio formation both in banking institutions and in the banking system.

\section{Theoretical, Empirical and Methodological Grounds of the Research}

The current crisis, which took place in 2008, sharpened the problems in the economy of the Russian Federation and in the banking sector. It displayed itself in restrictions of access to external funding, which, in its turn, had a negative influence on expansion of crediting, cost of credit resources and had an adverse effect on the capital base of banking institutions. Efficient monitoring of capital portfolio quality is impossible without taking into consideration the challenges of the time and new financial realities. Achieving the highest level of capital portfolio quality should be combined with an increase in the role of bank crediting to ensure sustainability and stability of national economic development (Grebenik, 2014). Due to this fact, a careful analysis must be given to the specific circumstances in which the banking institution operates, and analytical estimation must be given to the category of "the bank's capital portfolio" (Rupeika-Apoga et al., 2018).

Many experts believe, that the crisis resulted in "swift and widespread" deterioration in the quality of banking institutions' activity due to exposure to adverse macroeconomic, institutional, regulatory, and other effects, which manifests itself in incapability of many credit organizations and, in some cases, of the whole banking system to fulfill their fundamental functions in economy to progress and to perform basic and other operations. This has led to the increased demand for scientific studies concerning balancing of different banking transactions, as well as the need 
for a diversified approach to the management of the bank's assets and liabilities. This fact is particularly relevant in the case of capital portfolio. In our opinion, a capital portfolio is an aggregate of funds (both owned and borrowed) classified upon various quality criteria, whose adequacy promotes banking institutions' consistent and successful performance.

A meaningful, categorical definition of the banking institution's capital portfolio must be given with account for the quality attribute. Capital portfolio quality must be estimated through its ability to provide the highest level of the banking institution's revenue with enough level of liquidity and risk. In addition, an intrinsic feature of the notion of quality is need satisfaction. The New Encyclopedia of Philosophy suggests the following definition: quality is a category expressing an object's integral, substantial distinctness, which differentiates this object from other objects. The contemporary dictionary of economics defines quality as a set of features, properties, characteristics of a production, goods, work, services, labor, which stand behind their ability to meet people's needs and demands, correspond to their purpose and specified requirements. Based on the above-mentioned, it is proposed to introduce a new criterion for the capital portfolio quality - purposefulness, which characterizes capital portfolio's orientation and ability to satisfy economic needs to support the most significant tendencies with resources, which therefore identifies the capital portfolio's long-term competitiveness (Posnaya et al., 2018a).

The timeliness of this approach is supported by the results of the studies on the current key aims of the banking system's activity, the change in conceptual approaches to the main function of banking institutions as financial intermediaries under post-crisis conditions. The notion of quality is also characterized by complexity and versatility. Economic papers often equate an object's characteristics and quality. It is argued that a characteristic is an object's attribute, manifestation of its quality. In addition, characteristics can manifest themselves in the process of objects' interaction. In this context, a range of individual characteristics can become obvious in aggregated form. In case of capital portfolio, its aggregated characteristic is a structured set of funds (Posnaya et al., 2018b). As for capital portfolio quality, characteristics can be identified and represented as quantitative and qualitative indices.

The identified indices are compared against criteria, which represent a comparison base, and allow to receive the most adequate assessment of the banking institution's capital portfolio quality. In practice, it seems possible that banking institutions pay fundamental attention to assessment of capital portfolio quality from the point of view of its risk. Additionally, to this key feature, it seems relevant to use a complex approach, which suggests paying attention to all quality indices mentioned above.

Development and implementation of the complex approach to estimation of capital portfolio quality is promoted by implementation of the integral quality estimation. The approach based on the integral quality estimation suggests: 
- compulsory examination of a set of various criteria when estimating capital portfolio quality;

- determination of different levels against the criteria based on the indices planned by the banking institution;

- full estimation and analysis of variance between plan and actual against the main indices;

- calculation of an aggregate qualitative index for capital portfolio regarding weights of different variables with difference between plan and actual;

- analysis of factors influencing the integral quality index;

- implementation of specific policies to increase the level of capital portfolio quality in the implementation of external and internal impact on the factor that has had the most significant impact on the change in the quality characteristics of the capital portfolio. For example, under the most significant influence of the capital portfolio risk level, certain measures must be taken aiming at capital risk optimization; if a lower portfolio quality is conditioned by its profitability level, it is necessary to search for ways to reduce the cost of resources, or for the most favorable niches in the banking market.

The necessity of efficient banking management is obvious. The system of management of the bank's capital portfolio quality represents a complex of interconnected elements, including principles, a mechanism and steps. In this, capital portfolio quality is the backbone principle of the management system.

When considering the most significant characteristics of capital portfolio quality management, common approaches to financial management in the bank must be considered. The process of management can be presented as a situation where the subject of management influences the object of management through a range of tools, techniques, methods, whose main goal is to reach pre-determined results. The group of these tools, techniques, and methods depends on the macroeconomic situation and constitutes the management sequence (Posnaya et al., 2017). The subjects of management are legislative and executive authorities, founders of organizations, managers, economists, and others.

Management objects are incomes, profit, funds, labor costs, quality, etc., (Raisberg et al., 2005). From this point of view, economic entities implement the policy of management of certain categories: liquidity, assets, liabilities, profitability, risks, capital. In applied management, a policy is the whole set of measures taken by the subject of management to reach a certain pre-determined goal of the bank's activity. For example, Rose (1995) considers quality management to be a means of protection from risks, i.e., measures taken to solve economic problems and avoid a higher level of their severity. Grebenik (2014) considered quality management as a minimum risk of banking institutions' bankruptcy, a higher level of the bank's credibility and the effect of banking institutions' insurance. 
Based on the definitions of quality mentioned above, it can be concluded that capital portfolio quality management is a predominant management orientation for a bank. Thus, the aim of the banking institution's capital portfolio quality management is to organize efficient provision of banking products and services to clients, to secure dynamic development of the bank, to provide financial stability through optimization of the capital portfolio's components.

The study suggests that the key goal of the banking institution's capital portfolio quality management is to solve the following tasks: development of the system of capital portfolio management; timely determination of the dominant factors of external and internal functioning environment; implementation of the system of permanent monitoring for the indices of the quality level of a banking institution's capital portfolio.

Summing up, it can be concluded that the banking institution's capital portfolio quality management is an independent subsystem of the whole banking management system, mainly aiming at minimizing the level of risk of the banking institution's activity through implementation of a set of the main activities, providing for a flexible connection between the risk, liquidity, profitability, purposefulness of the key banking transactions, whose volume and profitability depend on the capital portfolio. The banking institution's capital portfolio quality management involves an organization based upon certain principles with the use of a certain mechanism.

Therefore, a bank's efficient capital portfolio quality management requires recognition of the main scientific principles underlying its organization. Understanding of importance of these standpoints helps identify and classify the main principles of the banking institution's capital portfolio quality management.

Identification of the main principles of the capital portfolio quality management must be carried out through the study of the current objective laws and regularities of the banking institution's activity concerning capital management. Taking this into account, we can identify the main principles of the banking institution's capital portfolio quality management:

1) special purpose orientation - management aiming at the key goal of forming the capital portfolio for profit-making;

2) comprehensive coverage - simultaneous coverage of all spheres of banking activity concerning capital formation;

3) multi-level character - capital portfolio quality management is carried out at all levels of the banking institution;

4) full range analysis - analysis of economic and non-economic indices of banking activity, influencing the aggregate risk level;

5) transparency - capital portfolio quality is affected by multiple external and internal factors; 
6) consistency - portfolio quality management is carried out during the whole term of the banking institution's activity;

7) sequencing - maintaining an intrinsic link of every stage of capital portfolio quality management both functionally and organizationally;

8) identification of dynamics and perspectivity - analysis of factors, which influenced capital portfolio quality in the prior period and their outlook projection.

Equally important are the following additional principles, which contribute to the formation of capital portfolio with given characteristics. Thus, the additional principles are:

- identification of the main priorities - paying attention to the bank's shareholders and the main capital resources;

- selectivity - cooperation with the clients having sustainable business;

- rigid balance - a clear correspondence of terms and volumes between the available resource base and loans provided;

- correspondence of available and re-attracted funds to the volume of the owned capital and its adequacy, to the level of obligatory prudential standards issued by the Bank of Russia;

- targeting - correspondence to strategic aims of development of the bank and economy as a whole;

- changeability - constant changing of the portfolio's volume and structure.

Following the principles above will help the bank to implement efficient banking policy in terms of capital portfolio quality management. Thus, the mechanism of capital portfolio quality management can be presented as a set of interconnected elements: methods, tools, regulatory support, information support, and other factors encouraging stability of the banking institution. The main elements of capital portfolio quality management are presented in Figure 1.

Figure 1. Elements of the bank's capital portfolio quality management

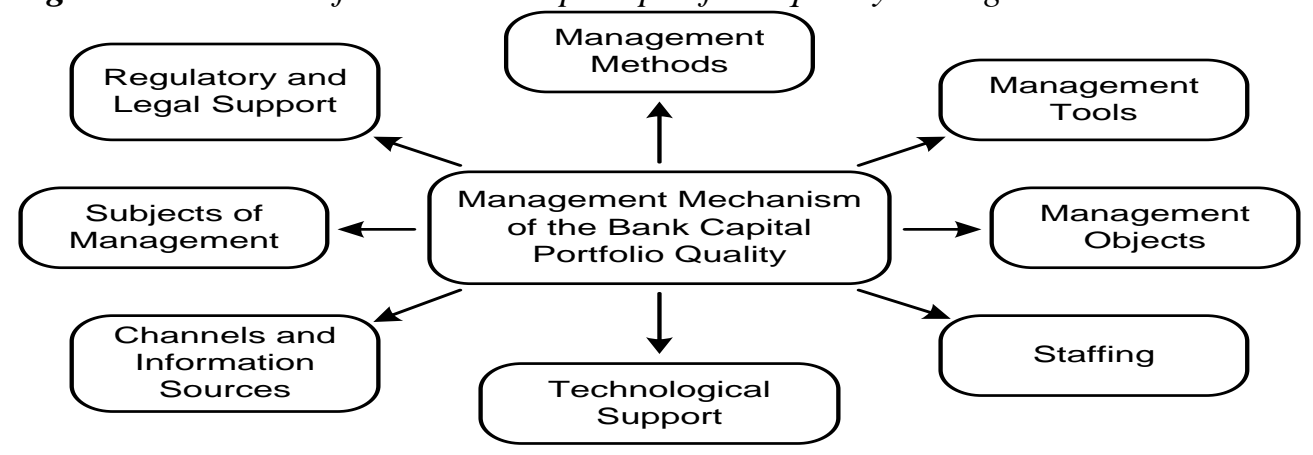

Figure 2 provides a schematic view of measures at the main stages of capital portfolio quality management. 
Figure 2. The sequence of the main stages of capital portfolio quality management

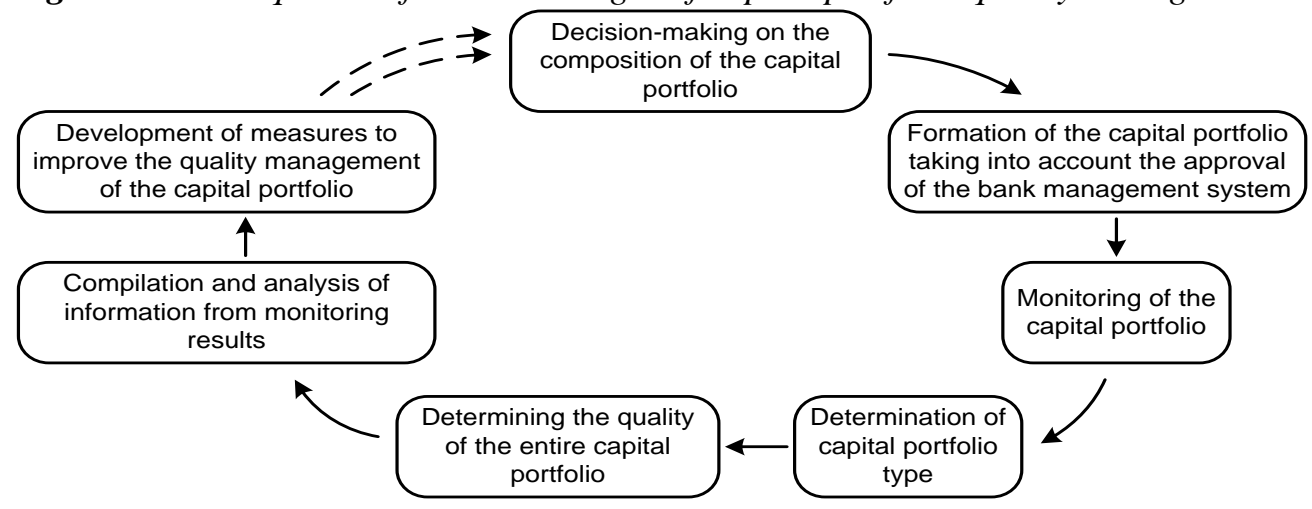

When implementing capital portfolio quality management, it seems reasonable to apply specific scientific methods. Ultimately, the main methods of capital portfolio management are insurance, hedging, limiting, diversification. Liquidity management relates to the use of the main methods, for example, fund sources unification and separation, determination of financial ratios, regulation, etc. While managing the bank's income, it is advisable to take into consideration the regional social-economic strategy, its area of functioning, the macroeconomic condition of the country in general and the region.

\section{Results}

Efficient capital portfolio quality management must include formation of optimal structure of capital portfolio, its correspondence to the current situation and the maximum level of return. Capital portfolio quality monitoring is implemented through a system of indices and indicators, it promotes prevention of different risks and timely activities on their management. The indicators determine results (effect), as well as efficiency of the whole banking activity, which directly influences the banking institution's capital portfolio. They serve as a comparison base and have threshold values. Banking practices demonstrate that ignoring critical indices leads to bankruptcy of the banking institution. Estimation of efficiency of capital portfolio quality management can include not only quantitative, but qualitative criteria as well. Thus, efficiency of a banking institution's capital portfolio quality management depends on well-qualified and appropriate management organization, which simultaneously and systematically considers all factors, which influence this process and do not contradict legislation in terms of capital portfolio formation.

\section{Conclusions and Recommendations}

It must be concluded and taken into consideration that a high-quality capital portfolio of the banking institution cannot be formed without banking monitoring 
activities. The monitoring tools, which can be attributed to the bank's capital portfolio, include the following:

- definition of priority tools used for the capital portfolio formation and maintenance of its adequacy;

- working out of the capital portfolio's potential structure;

- definition of quantitative and qualitative characteristics of the capital portfolio, determination of their criterial values and control over the actual values' correspondence to the set ones;

- the choice of values for estimation of working capital efficiency;

- establishment of limits, including boundaries or a lower limit of the actual capital adequacy value; in case actual values get close to the set limits, procedures should be provided for preparing and making appropriate decisions to return the actual values within the established framework.

\section{References:}

Bortnikov. G.P. 2007. Economic Capital as a Management Tool. Management in a Credit Institution, 5, 45-52.

Grebenik, T.V. 2014, Modern Features of Effective Quality Management of the Loan Portfolio. Naukovedenie (Internet Journal), Moscow, 5(24), 1-11.

International Convergence of Capital Measurement and Capital Standards: A Revised Framework Basel, http://www.bis.org/publ/bcbs /07.htm.

Kryksin, G.V. 2005. Formation of the development strategy of regional banks as a condition for increasing business activity. Thesis, Moscow.

Mahboud, R. 2017. Main Determinants of Financial Reporting Quality in the Lebanese Banking Sector. European Research Studies Journal, 20(4B), 706-726.

Milenkov, A.V. 2005. Improving the methodology for assessing the stability of the regional banking system. Thesis, Moscow.

Posnaya, E.A., Tarasenko, S.V., Vorobyova, I.G., Dobrolezha, E.V. 2018a. Methodology and Results in Bank Capital Assessment. European Research Studies Journal, XXI, Special Issue 1, 518-524.

Posnaya, E.A., Kolesnikov, A.M., Antokhina, Y.A. 2018b. Application features of capital estimation methods in the bank management system. St. Petersburg State Polytechnical University Journal. Economics, (3), 161-174.

Posnaya, E., Semeshina, N., Vorobyova, I., Mohnitskaya, D. 2017. Selective Method of a Bank Capital Assessment in Russian Federation and Other Country in the Context of Globalization. Proceedings of the 17th International Scientific Conference on Globalization and its Socio-Economic Consequences. Rajecke Teplice, Slovakia, (Part 4), 2089-2095.

Raisberg, B.A., Lozovsky, L.Sh., Starodubtseva, E.B. 2005. Modern Economic Dictionary. INFRA-M, Moscow.

Rose, P.S. 1995. Banking Management. Delo, Moscow.

Rupeika-Apoga, R., Zaidi, H.S., Thalassinos, E.Y. \& Thalassinos, I.E. 2018. Bank Stability: The Case of Nordic and Non-Nordic Banks in Latvia. International Journal of Economics \& Business Administration, 6(2), 39-55. 